\title{
A new subspecies of Manchurian pika Ochotona mantchurica (Lagomorpha, Ochotonidae) from the Lesser Khinggan Range, China
}

\begin{abstract}
Andrey A. Lissovsky
ABSTRACT. I examined 14 craniometric features of 128 specimens of Ochotona mantchurica from the entire distribution range. A craniometric analysis revealed at least three major groups with detached geographical distribution. The race of $O$. mantchurica from the southern part of the Lesser Khinggan Range has the same level of morphological peculiarity as two other subspecies: $O$. m. scorodumovi from the Russian Transbaikalia and O. m. mantchurica from the Greater Khinggan Range, together with the northern part of the Lesser Khinggan Range. The distribution area of this race is separated from the rest of the species distribution range by a wide band of lowly suitable habitats. No nominal taxa were described from the southern part of the Lesser Khinggan Range, and the race in question was described here as a new subspecies: O. m. loukashkini ssp. nov.
\end{abstract}

KEY WORDS: Manchurian pika, Ochotona mantchurica, craniometry.

Andrey A. Lissovsky [andlis@zmmu.msu.ru], Zoological Museum of Moscow State University, Bolshaya Nikitskaya 6. Moscow 125009, Russia.

\section{Новый подвид манчжурской пищухи Ochotona mantchurica (Lagomorpha, Ochotonidae) с хребта Малый Хинган, Китай}

\begin{abstract}
А.А. Лисовский
РЕЗЮМЕ. Проанализирован набор из 14 краниометрических признаков от 128 экземпляров Ochotona mantchurica со всего ареала вида. Краниометрический анализ показал наличие как минимум трёх основных групп с разобщенным географическим распространением. Форма O. mantchurica из южной части Малого Хингана морфологически обособлена на том же уровне, как и два других подвида: $O . m$. scorodumovi из Забайкалья и $O . m$. mantchurica с Большого и северной части Малого Хинганов; область распространения этой формы отделена от остального ареала вида широкой полосой малопригодных местообитаний. В южной части Малого Хингана прежде не было описано номинальных таксонов пищух, и упомянутая форма описана здесь как новый подвид O. m. loukashkini ssp. nov.
\end{abstract}

КЛЮЧЕВЫЕ СЛОВА: манчжурская пищуха, Ochotona mantchurica, краниометрия.

\section{Introduction}

Manchurian pika Ochotona mantchurica Thomas, 1909 is a petrophilous species of pika, which belongs to the "alpina" species group. It is closely related to $O$. hyperborea (Pallas, 1811) (Lissovsky et al., 2008). This species is distributed to the south of the AmurShilka-Onon Rivers course, except for a narrow mountain range in the extreme west. In Russia, this range is known as the Ermana Range, and in Mongolia, it is known as Ereeniy Nuruu. The remaining territory in the Russian South-East Transbaikalia region and the uplands of the Greater and Lesser Khinggan Ranges in China is inhabited by Manchurian pika.

Ochotona mantchurica was first recognised as an independent species only several years ago (Lissovsky, 2005; Lissovsky et al., 2007, 2008), and was previously being split between two species, including O. hyper- borea and O. alpina (Pallas, 1773). This last fact is still a cause of taxonomical confusion. Being distributed in two countries, $O$. mantchurica was studied separately by Russian and Chinese authors. All the Russian taxonomists who distinguished between $O$. alpina and $O$. hyperborea, attributed the race of $O$. mantchurica from the territory of the Russian Transbaikalia region to the subspecies of $O$. alpina - O. a. scorodumovi Skalon, 1935 or O. a. cinereofusca (Schrenk, 1858); pikas from both the Greater and Lesser Khinggan Ranges were listed as O. h. mantchurica (Ognev, 1940; Yakhontov \& Formozov, 1992; Sokolov et al., 1994). This point of view was cited in several checklists (Smith et al., 1990; Hoffmann \& Smith, 2005). Chinese taxonomists treated Manchurian pikas from the Greater and Lesser Khinggan Ranges as distinct subspecies belonging to two different species: $O$. h. mantchurica and $O$. a. cinereofusca, respectively (Feng \& Zheng, 1985). The last 
point of view merits special attention, since only these last cited authors studied data from both the Khinggan Ranges.

The name cinereofusca was discussed in several recent papers. With regard to pikas comprising the type series of Lagomys hyperboreus var. cinereofusca (Schrenk, 1858) (the location of the type specimens is unknown since the time of the initial description), these specimens were collected on the left bank of the Shilka River, where only representatives of $O$. hyperborea were previously found (Yakhontov \& Formozov, 1992; Lissovsky et al., 2008). Thus, the name cinereofusca belongs to the synonymy of the latter species. Formozov and Baklushinskaya (2011) reviewed the taxonomical assignment of cinereofusca again, and came to uncertain conclusions. The authors designated the lectotype specimen collected at the left bank of the Shilka River, but they concluded that the dialog about whether the name cinereofusca should be attributed to Manchurian pika should not be considered as a settled issue. At the same time, this last paper does not contain original material on the cinereofusca type specimens or on pika distribution in the Shilka area, and instead, discussed data that was published previously (Yakhontov \& Formozov, 1992; Lissovsky et al., 2008), including field investigations in all available pika habitats along the Shilka River (Lissovsky et al., 2008).

This paper is devoted to evaluating intraspecific variation within $O$. mantchurica, in order to assess the taxonomic status of Manchurian pikas originating from the Lesser Khinggan Range.

\section{Material and Methods}

I examined $O$. mantchurica in the following collections: the Institute of Zoology, the Chinese Academy of Science (IOZCAS, Beijing); the Zoological Museum of Moscow University (ZMMU, Moscow); the Northwest Institute of Plateau Biology of the Chinese Academy of Science (NWIPB, Xining); the Zoological Institute of the Russian Academy of Sciences (ZIN, Saint Petersburg); the Natural History Museum (NHM, London); the Zoological Museum of Irkutsk University (IGU, Moscow); the Museum der Naturkunde (MNB, Berlin); the Field Museum of Natural History (FMNH, Chicago); the Smithsonian Institution (USNM, Washington DC); and the Harbin Normal University (HNU, Haerbin). The sample consisted of 128 intact skulls and more than 250 skins, and included the type specimens of mantchurica and scorodumovi (Appendix 1). Fourteen measurements were taken on each skull, using calipers with an accuracy of $0.01 \mathrm{~mm}$, as follows: the condylobasal length (KBD), the length of the palatine foramen (NOTV), the upper diastemal length (DIAST), the alveolar length of the maxillary tooth row (DVKR), the rostral length (from the anterior edge of the premaxillary bones to the posterior edge of the maxillary toothrow alveoli) (DLITS), the zygomatic breadth (SKW), the length of the auditory bulla (DBAR), the maximal width between the lateral edges of the auditory bullae (WSB), the maximal length of orbit (DG), the maximal width of orbit (WG), the interorbital constriction (MG), the postorbital constriction ( $\mathrm{ZGW})$, the general skull height $(\mathrm{H})$, and the general height of the mandible $(\mathrm{HNCH})$. The scheme of measurements was published previously (Lissovsky, 2014). All calculations were carried out on $\log (10)$ transformed measurements to linearize age variation (Mina \& Klevezal, 1976).

Sexual dimorphism was ignored, since it was not found in pikas of the "alpina" group (Lissovsky, 2003). Age was assigned to one of three groups: (1) an obvious juvenile with undeveloped crests on the mandible and an arc-shaped profile of the skull, together with shortened nasals; (2) subadults with fully developed skull profiles, but with undeveloped crests on the mandible; and (3) adults (Lissovsky, 2004).

To exclude age bias, I used an orthogonal projection of the initial data along the vector of the age variation (Burnaby, 1966). The vector of the age variation was calculated as the first eigenvector of the between-group covariance matrix, which was computed with a nested two-factor MANOVA, in which the variable containing the three age gradations, as well as the identifier of the geographical sample, were used as the grouping variables. The age factor was nested in the geographical sample. I used age classes 1 and 3 to calculate the covariance matrix in order to minimize errors arising from the inaccuracy in the determination of age class 2 (Lissovsky, 2004; Obolenskaya et al., 2009).

The following approach was applied as an ordination method: first, the eigenvectors of the within-group covariance matrix (with geographic samples as groups) of the dataset with reduced age were calculated. Secondly, the initial data matrix was multiplied with the matrix of the eigenvectors. Thus the initial data was rotated into the space of the intergroup variation without distortion of the initial space (Obolenskaya et al., 2009).

The samples for the hierarchical cluster analysis included only specimens that were collected in the same locality. Only samples with $n>4$ were used in the cluster analysis (13 samples, Appendix 1). Cluster analysis was performed based on a matrix of Mahalanobis distances, using the unweighted pair group method with arithmetic mean (UPGMA). The bias induced by using samples of different sizes was corrected (Marcus, 1993). In order to check for the stability of the obtained clusters, I carried out cluster analysis on the basis of a dataset prepared for ordination, excluding the last factors (which explained less than $5 \%$ of the general variance altogether) of the dataset in different combinations. The belonging of the smaller size samples $(n<4)$ to one of the clusters, obtained in hierarchical cluster analysis, was evaluated using nonlinear discriminant analysis, with cluster identifier as a grouping variable. The difference between the clusters in cranial measurements was evaluated using one-factor ANOVA.

Standard modules of Statistica, version 8 (Statsoft Inc., 2007), as well as algorithms written by the author 


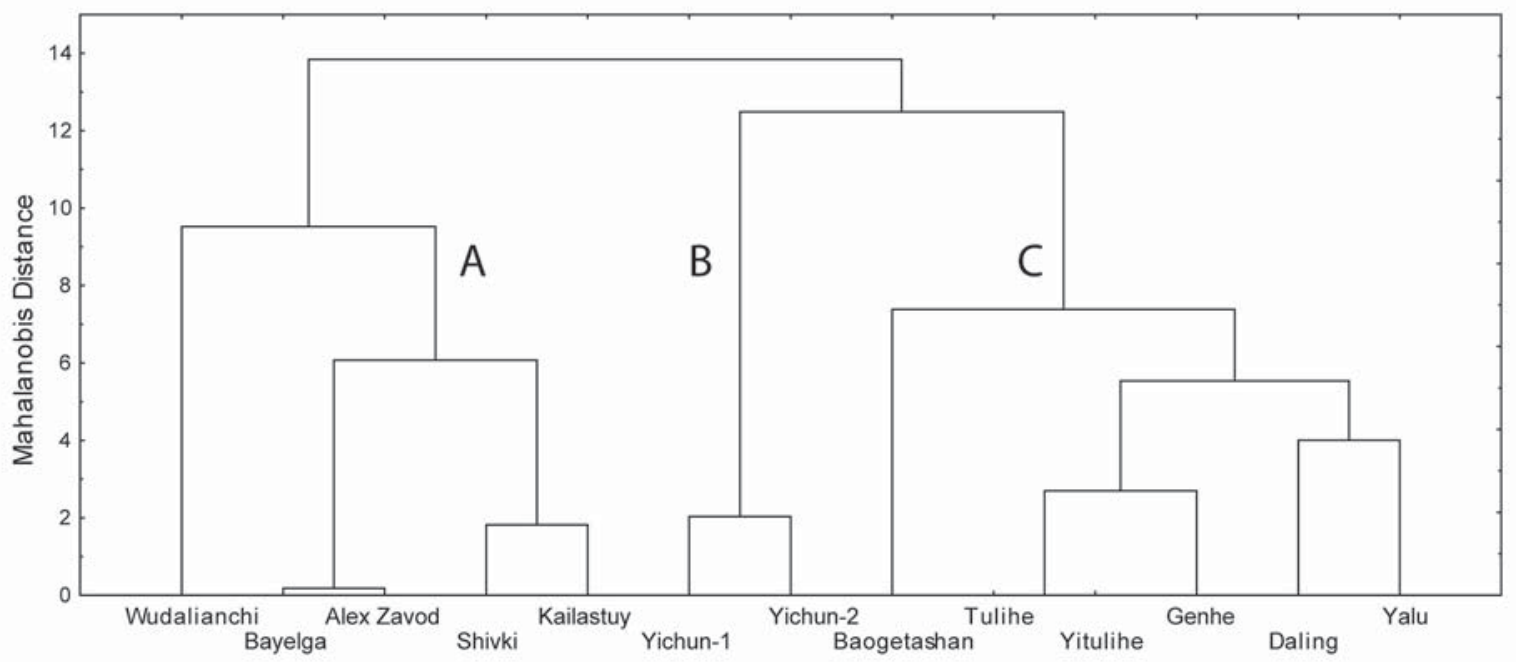

Fig. 1. Dendrogram showing results of hierarchical cluster analysis of craniometric features of Ochotona mantchurica geographical samples. For an explanation of sample labels, refer to Appendix 1.

in STATISTICA Visual Basic, were used in the craniometric analyses.

I used a dataset of geographical coordinates of 24 museum records of $O$. mantchurica for species distribution modelling. The following environmental layers were taken for calculations:

1) A remote survey from the scanning system $\mathrm{MO}$ DIS of the Terra satellite, with a resolution of $500 \mathrm{~m}$ (http://glcfapp.glcf.umd.edu:8080/esdi/). I used generalised average monthly data for all months, 2004: 77 layers.

2) WorldClim global climate data with a resolution of $30^{\prime}$ (>1 km) (http://www.worldclim.org). I used 19 "bioclimatic" variables that are hypothetically relevant to the distribution of biological objects (Hijmans et al., 2005).

3) Data on altitudes, slopes steepness, and slope curvature.

All environmental layers were converted to the rasters with a pixel size of $0.02^{\circ}$ and longitude/latitude geographical projection. The project was restricted by the limits of the Amur River basin and the adjacent Uldza-Hailar undrained area. The layer for correction of data collecting bias was compiled on the basis of analysis of all collecting localities of small mammals from the studied territory.

Initial standardized variables were transformed into mutually orthogonal variables using principal component analysis (climate and satellite data were transformed separately). Factors with an obviously "noisy" spatial distribution were excluded from further analysis. Input of the initial environmental layers in the final model was analysed on the basis of the correlation matrix between them and the principal components.

Maxent 3.3.3k (Phillips et al., 2006; Phillips \& Dudik, 2008) was used for species distribution model- ling; Scanex Image Processor v.4.2.14 was used for raster processing. Mapping was performed using the GIS package Mapinfo 11.0.

\section{Results}

Cluster analysis of the craniometrical features (Fig. 1) displayed 3 major groups within $O$. mantchurica. They roughly corresponded to the 3 taxa mentioned in the Introduction. One of them (Fig. 1 cluster A), united the pikas from the Russian Transbaikalia - the Shilka and Argun' Rivers interfluve. Another (Fig. 1 cluster B) comprised pikas from the southern part of the Lesser Khinggan Range. The last (Fig. 1 cluster C) united samples from both the Greater Khinggan Range and the northern part of Lesser Khinggan Range. The position of a sample from Wudalianchi, Heilongjiang, China was unstable. Depending on the variants of noise reduction, it was clustered either to group A (Fig. 1) or to B (not shown). A Discriminant analysis of the craniometrical features displayed a similar geographical affiliation of samples that were not included into cluster analyses due to their small size (Fig. 2). Ordination results are shown in Fig. 3.

Differences between these three groups were significant in all measurements except for orbit parameters. It is difficult to verbalize the differences because of the large overlap of cluster members (Fig. 3). Thus, clusters differed in some particular shape peculiarities. The best differentiation, which could be obtained from single cranial measurements, is presented in Fig. 4. Pikas from the cluster B, on average, had slightly shorter palatine foramen and wider zygomatic breadth.

Groups described above slightly differed in pelage coloration, which can be noted in a comparisons of series. Pikas from the Russian Transbaikalia in the 


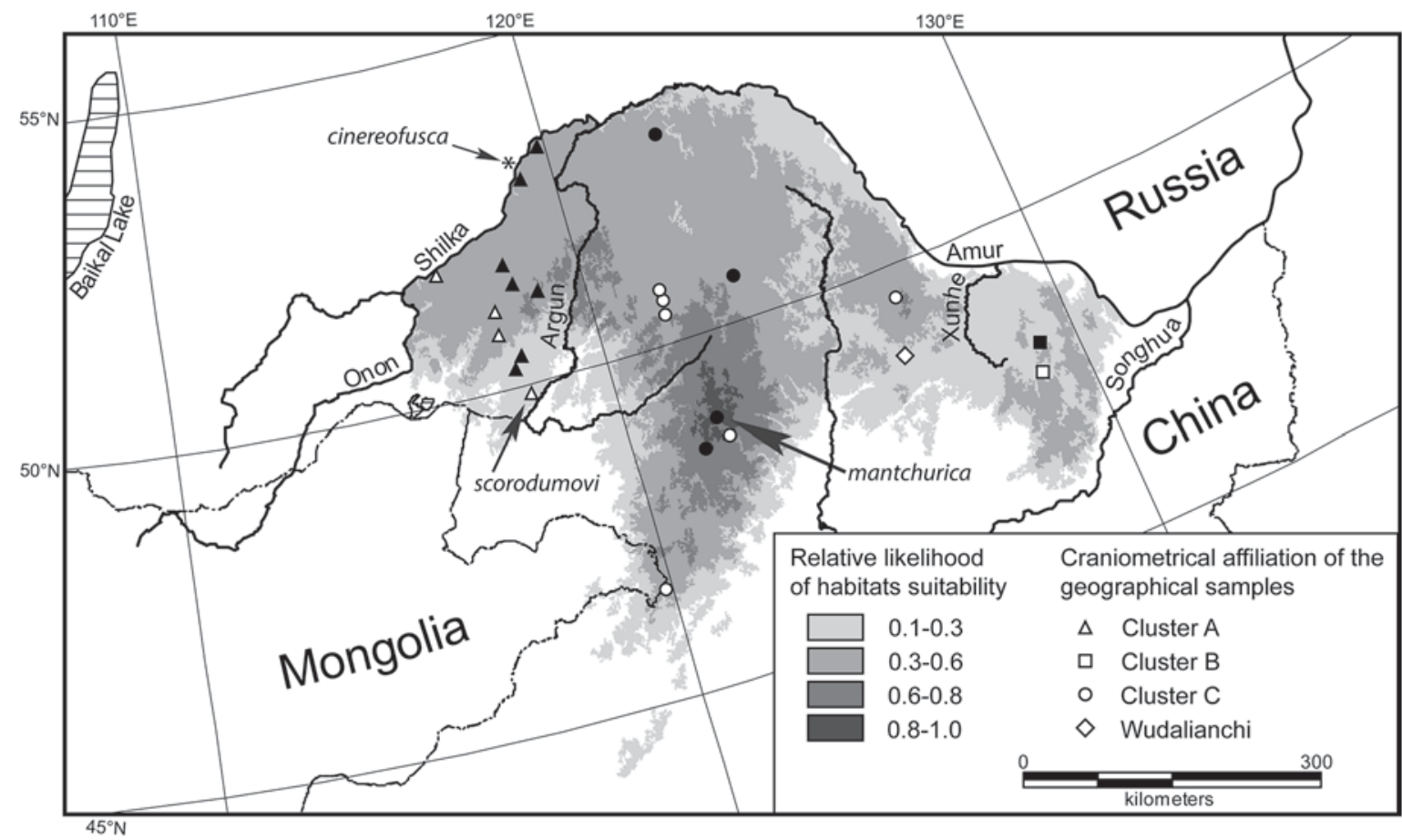

Fig. 2. Distribution model of Ochotona mantchurica with localities of studied specimens shown. Symbols reflect affiliation of each sample to one of the clusters from Figure 1. Symbols of geographical samples, whose affiliation was studied using discriminant analysis are filled with black. Type localities of nominal taxa, described from the studied territory, are marked with arrows; type locality of cinereofusca is shown with asterisk. The map is in Kavrayskiy's equidistant conic projection.

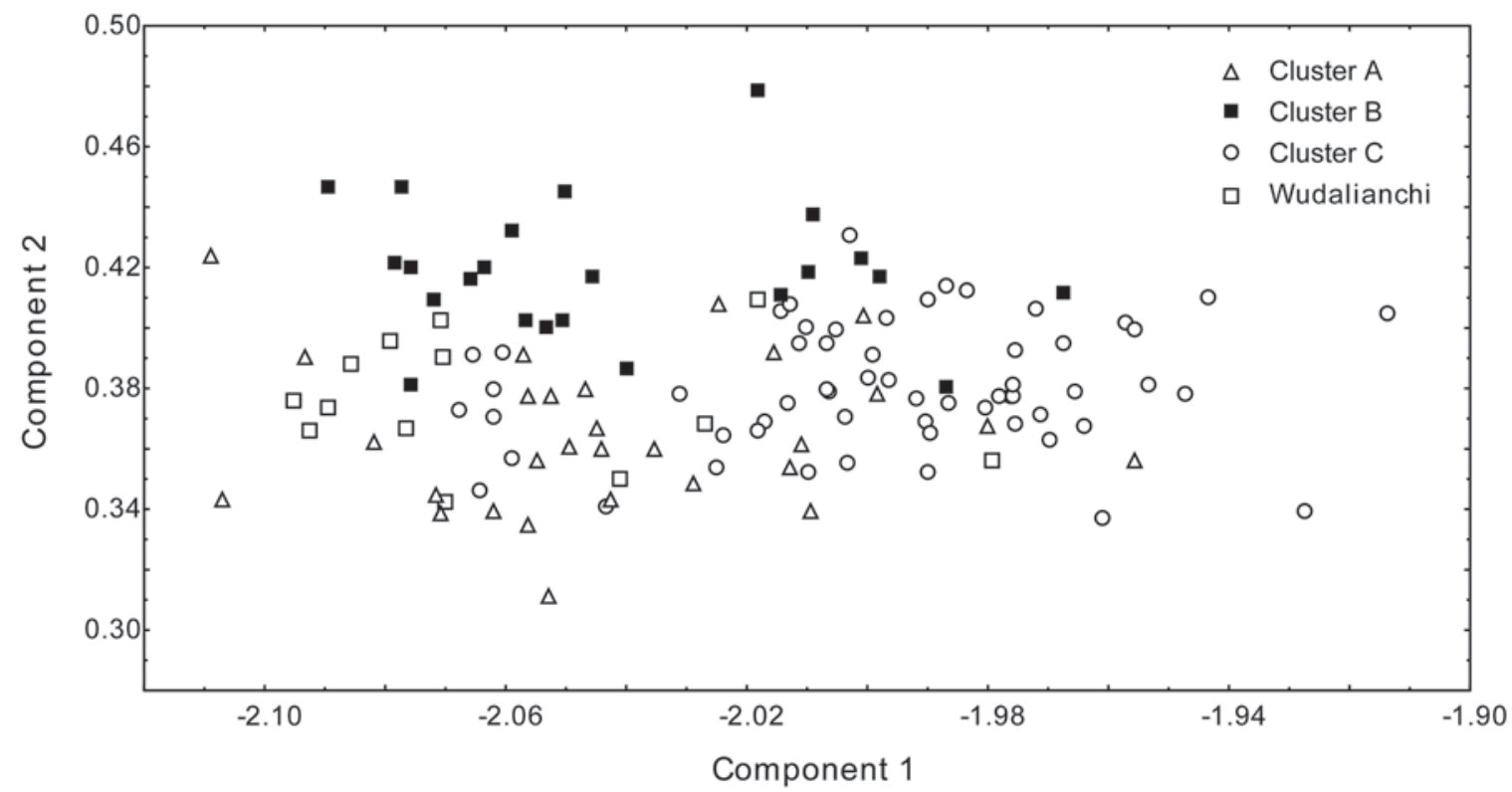

Fig. 3. Distribution of Ochotona mantchurica specimens in the space of maximized between-sample craniometric differences. The first component explains $42.4 \%$ of total variance; the second - 18.4\%. Cluster labels refer to Figure 1 . 


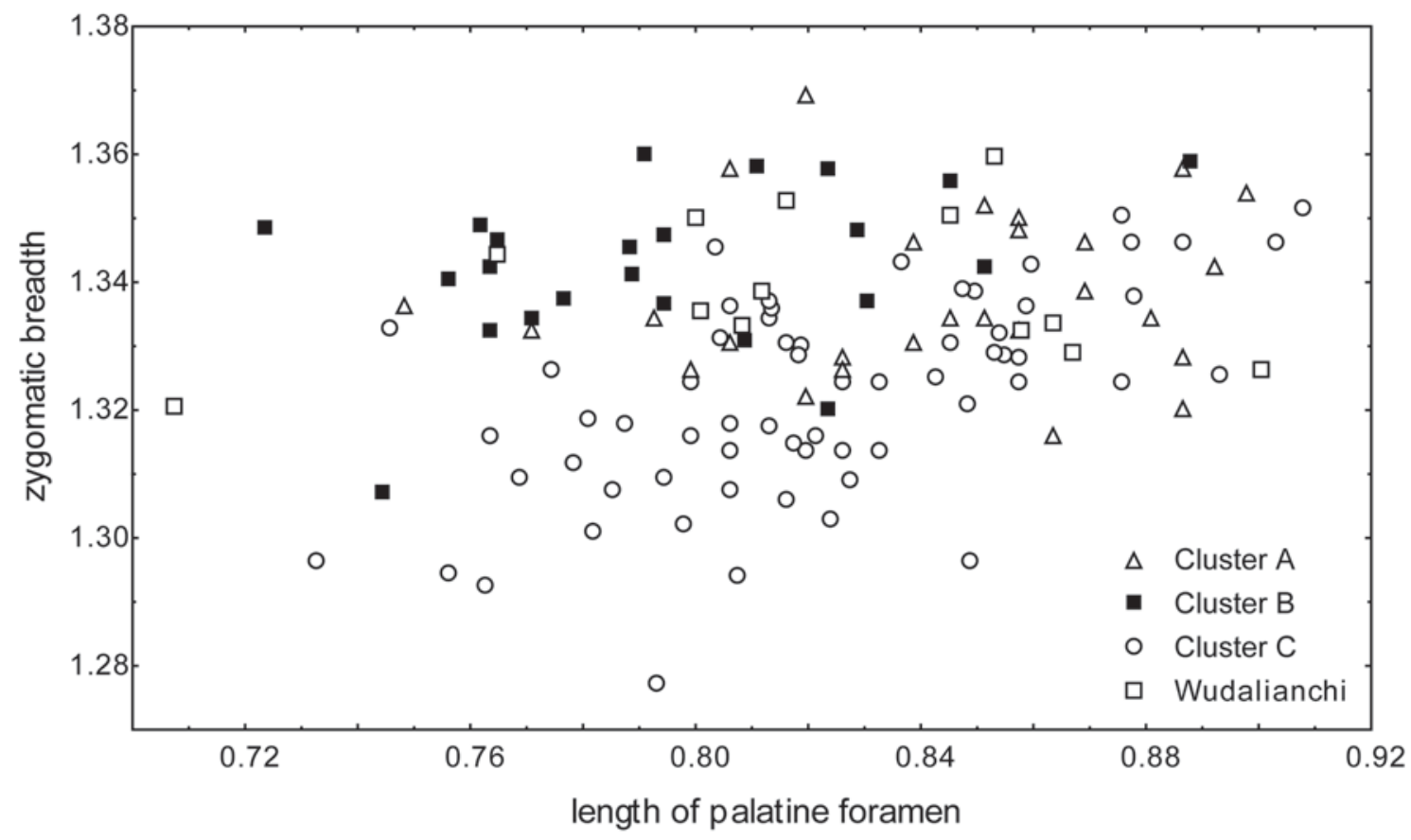

Fig. 4. Distribution of Ochotona mantchurica specimens in the plain of the two cranial measurements, logarithmic scale used. Cluster labels refer to Figure 1.

summer had an ochraceous brown dorsal part and sides with a darker dorsal stripe, while the ventral part was ochraceous. Skins from Greater Khinggan and the northern part of Lesser Khinggan Ranges showed that the brown dorsal part sparkled with both light and dark hair tips, the sides were ochraceous, and the ventral part was sandy. Pikas from the southern part of the Lesser Khinggan Range had a dorsal part that was rufous brown with a darker dorsal stripe, and the sides and ventral part were ochraceous. In the winter pelage, the skins from the southern part of the Lesser Khinggan Range preserved an ochraceous colour of the ventral part, while in other parts of the range the ventral part of the skin became greyer.

Habitat suitability analysis showed a predominance of a habitat of low suitability in the central part of the Lesser Khinggan Range and an isolated position of the southern populations from the Range. Permutation test revealed the importance of the following environmental factors in the formation of the distribution range: winter precipitation $(25 \%)$, winter temperature $(23.1 \%)$, slopes steepness $(11.8 \%)$, mid-winter soil moisture $(9.2 \%)$, and altitude $(8.6 \%)$.

\section{Discussion}

Morphological analysis displayed three clearly separated groups within $O$. mantchurica, which correlated in general with the geographical pattern. Such a level of morphological difference is a rare case within the "alpina" species group, which consists of very uniform pikas
(Lissovsky, 2003). Considering this fact, morphological separation is worthy of special attention.

Craniometrical results (Fig. 1) support the segregation of $O . m$. scorodumovi from the Russian Transbaikalia (Fig. 1 cluster A). The distribution area of this taxon is separated from O. m. mantchurica (Fig. 1 cluster C) from the Greater Khinggan Range by only the Argun' River. This river likely plays the role of a physiographic barrier which prevents an active gene flow.

Cluster analysis (Fig. 1 cluster B) unites together pikas from the northern part of the Lesser Khinggan Range with the pikas from the Greater Khinggan Range, except for the sample from Wudalianchi, which should be investigated further using additional material. Habitat suitability analysis (Fig. 2) shows that these two regions are not separated by low suitable habitats.

Another concordance in the morphological and zoogeographical patterns is a separation of the race from the southern part of the Lesser Khinggan Range. The wide gap in suitable habitats that corresponds to the lowland part of the Range in the Xunhe River basin can effectively prevent the migration of pikas from between the northern and southern parts of the Range. The level of morphological divergence of the pikas from the southern part of the Lesser Khinggan Range is comparable with the difference between $O . m$. scorodumovi and $O$. $m$. mantchurica. Taking into account its morphological and geographical separation, this race from the southern part of Lesser Khinggan Range should be recognised as a distinctive subspecies of $O$. mantchurica. 
As mentioned in the Introduction, the synonymy of Manchurian pika includes only two names: O. (Pika) hyperborea mantchurica Thomas, 1909, described from the Greater Khinggan Range (Bukhedu vicinities) and O. alpina scorodumovi Skalon, 1935, described from the Russian Transbaikalia, not far from the Argun' River (Kailastuy) (Fig. 2). No nominal taxa were described from the Lesser Khinggan Range. The name cinereofusca belongs to O. hyperborea (Yakhontov \& Formozov, 1992; Lissovsky et al., 2008) and in any case, cannot be referring to the pikas from the southern part of the Lesser Khinggan Range, since the distance of about $900 \mathrm{~km}$ separates the race under discussion, and the collecting site of the cinereofusca type series is inhabited by at least two subspecies of $O$. mantchurica. Thus, there is no available name for the race originating from the Lesser Khinggan Range, and it should be named de novo.

It is not easy to provide any single working morphological trait to distinguish this new subspecies from $O$. $m$. mantchurica and $O$. m. scorodumovi, considering the general similarity in all the pikas of the "alpina" species group (Lissovsky, 2003) and the multidimensional character of found discrepancies between the three craniometrical clusters. The only suitable morphological feature that separates the species in this group is the shape of the suture between the incisive and maxillary bones; however, this feature is variable in O. mantchurica (Lissovsky, 2003). Cranial measurements widely overlap between species (Lissovsky, 2003), not to speak of subspecies. Quantitative differences that were found in this study, as well as in the previous study, refer to the combination of cranial features, reflecting partial peculiarities in the cranial shape. The best solution to differentiate the subspecies of $O$. mantchurica could be achieved by using molecular and bioacoustical markers, which have displayed a high diagnostic value in the "alpina" species group (Nikol'skii, 1984; Lissovsky, 2005; Lissovsky et al., 2007). However, such data are unavailable now and should be gathered in the future. It should also be mentioned that Niu et al. (2004) stated that they studied specimens from both of the Khinggan Ranges. This paper was published before the integrity of $O$. mantchurica had been discovered, and its results coincided with the prior taxonomical scheme (Feng \& Zheng, 1985): there was a clear difference between "O. alpina" from the Lesser Khinggan and "O. hyperborea" from the Greater Khinggan. A later study (Lissovsky et al., 2007) showed that the DNA sequence of "O. hyperborea" from the Greater Khinggan is identical to $O$. hyperborea from the northern clade which inhabits the northernmost parts of Russia only; the sequence of " $O$. alpina" from the Lesser Khinggan is identical to the only sequence of $O$. alpina from the Altai Mountains that was available in 2004. Besides this striking geographical contradiction, the sequence of " $O$. alpina" from the Niu et al. paper contains a short region (153 bp) inside cytochrome b with an abnormally high substitution level, including nonsynonymous substitutions that were identical to the specimen of $O$. alpina from the Altai Mountains and were not found in any other pikas (Lissovsky et al., 2007). Thus, it was concluded that Niu et al.'s (2004) data contained errors and the sequences should be used with caution (Lissovsky et al., 2007). The rest of the genetic data, available in GenBank on October 2015, contain only mitochondrial sequences from the Russian Transbaikalia and $\mathrm{Wu}-$ dalianchi (China), and cannot help in the comparison of pikas from the Khinggan Ranges.

\section{Ochotona mantchurica loukashkini ssp. nov.}

Holotype: IOZ CAS 03052, field code 32137, male, adult, skin and skull, collected in Yichun vicinities, Heilongiiang Province, China, 10 April 1954, collectors Fuzhang Zhou, Zhihua Jiang et al. The specimen is kept in the Institute of Zoology, Chinese Academy of Science, Beijing. Body mass $175 \mathrm{~g}$, body length $181 \mathrm{~mm}$, hindfoot length $25 \mathrm{~mm}$, ear length 18 mm, KBD $42.0 \mathrm{~mm}$, SKW $22.3 \mathrm{~mm}$.

Diagnosis: Manchurian pika, differs from $O . m$. mantchurica and O. m. scorodumovi in its shorter palatine foramen and wider zygomatic breadth; in the winter pelage, the skin has an ochraceous ventral part. Size of adult pikas skull: KBD: $39.0-44.0$, NOTV: 5.5-7.1, SKW: 20.8-22.9, HNCH: 16.7-18.5. Distributed in the southern part of Lesser Khinggan Range, Heilongjiang, China.

Ethymology: the subspecies is named in honour of the Russian zoologist Dr Anatole S. Loukashkin (19021988), who was one of the first scientists to initiate a purposeful study of the Manchurian region.

ACKNOWLEDGEMENTS. I would like to thank A. Averianov, G. Baranova, and O. Makarova (St. Petersburg); P. Jenkins (London); Q. Yang, D. Ge, and L. Xia (Beijing); W. Li (Xining); F. Mayer, R. Asher, R. Angermann, and I. Mann (Berlin); T. Sirokhina (Irkutsk); D. Lunde (Washington); and B. Patterson and W. Stanley (Chicago) for the opportunity to study their collections and for their invaluable help. I am also grateful for E. Obolenskaya's help in various issues. I thank B. Kryštufek and A. Abramov for their valuable comments on the manuscript.

Data collection was supported by the Russian Foundation for Basic Research, grant 14-04-00163; other study was supported by Russian Science Foundation, grant 14-50-00029.

\section{References}

Burnaby T.P. 1966. Growth-Invariant Discriminant Functions and Generalized Distances // Biometrics. Vol.22. No.1. P.96-110.

Feng Z. \& Zheng C. 1985. Studies on the pikas (genus Ochotona) of China - taxonomic notes and distribution // Acta Theriologica Sinica. Vol.5. No.4. P.269-290 [in Chinese and English].

Formozov N.A. \& Baklushinskaya I.Y. 2011. [Manchurian pika (Ochotona mantchurica scorodumovi) from the interfluve of the Shilka and Argun Rivers: karyotype and problems of pika taxonomy in Amurland and adjacent 
territories] // Zoologicheskii Zhurnal. Vol.90. No.4. P.490-497 [in Russian].

Hijmans R.J., Cameron S.E., Parra J.L., Jones P.G. \& Jarvis A. 2005. Very high resolution interpolated climate surfaces for global land areas // International Journal of Climatology. Vol.25. No.15. P.1965-1978.

Hoffmann R.S. \& Smith A.T. 2005. Order Lagomorpha // Wilson D.E. \& Reeder D.M. (eds.). Mammal species of the world: a taxonomic and geographic reference. 3rd. ed. Baltimore, MD: John Hopkins Univ. Press. Vol.1. P.185-211.

Lissovsky A.A. 2003. Geographical variation of skull characters in pikas (Ochotona, Lagomorpha) of the alpinahyperborea group // Acta Theriologica. Vol.48. No.1. P.11-24.

Lissovsky A.A. 2004. Contribution to age determination of pikas (Lagomorpha, Ochotonidae, Ochotona) // Russian Journal of Theriology. Vol.3. No.1. P.43-48.

Lissovsky A.A. 2005. [Comparative analyses of the vocalization of pikas (Ochotona, Mammalia) from alpinahyperborea group] // Byulleten' Moskovskogo Obshchestva Ispytateley Prirody. Otdel Biologicheskii. Vol.110. No.6. P.12-26 [in Russian].

Lissovsky A.A. 2014. Taxonomic revision of pikas Ochoto$n a$ (Lagomorpha, Mammalia) at the species level // Mammalia. Vol.78. No.2. P.199-216.

Lissovsky A.A., Ivanova N.V. \& Borisenko A.V. 2007. Molecular phylogenetics and taxonomy of the subgenus Pika (Ochotona, Lagomorpha) // Journal of Mammalogy. Vol.88. No.5. P.1195-1204.

Lissovsky A.A., Yang Q. \& Pilnikov A. 2008. Taxonomy and distribution of the pikas (Ochotona, Lagomorpha) of alpina-hyperborea group in North-East China and adjacent territories // Russian Journal of Theriology. Vol.7. No.1. P.5-16.
Marcus L.F. 1993. Some aspects of multivariate statistics for morphometrics // Contributions to morphometrics. Vol.8. P.95-130.

Mina M.V. \& Klevezal G.A. 1976. [Growth of Animals]. Moscow: Nauka. 291 p. [in Russian]

Nikol'skii A.A. 1984. Sound Signals of the Mammals in the Evolutionary Process. Moscow: Nauka. 199 p. [in Russian]

Niu Y., Wei F., Li M., Liu X. \& Feng Z. 2004. Phylogeny of pikas (Lagomorpha, Ochotona) inferred from mitochondrial cytochrome b sequences // Folia Zoologica. Vol.53. No.2. P.141-156.

Obolenskaya E.V., Lee M.-Y., Dokuchaev N.E., Oshida T., Lee M.-S., Lee H. \& Lissovsky A.A. 2009. Diversity of Palaearctic chipmunks (Tamias, Sciuridae) // Mammalia. Vol.73. No.4. P.281-298.

Ognev S.I. 1940. [Mammals of the USSR and Adjacent Countries]. Moscow-Leningrad: Izdatel'stvo AN SSSR. Vol.4. 616 p. [in Russian]

Phillips S.J., Anderson R.P. \& Schapire R.. 2006. Maximum entropy modelling of species geographic distributions // Ecological Modelling. Vol.190. No.3-4. P.231-259.

Phillips S.J. \& Dudik M. 2008. Modeling of species distributions with Maxent: new extensions and a comprehensive evaluation // Ecography. Vol.31. No.2. P.161-175.

Smith A., Formozov N., Hoffmann R., Zheng C. \& Erbajeva M. 1990. The pikas // Chapman J.A. \& Flux J.E.C. (eds.). Rabbits, hares and pikas: status survey and conservation action plan. Gland, Switzerland: IUCN. P.14-60.

Sokolov V.E., Ivanitskaya E.Y., Gruzdev V.V. \& Heptner V.G. 1994. [Mammals of Russia and Adjacent Regions: Lagomorphs]. Moscow: Nauka. 272 p. [in Russian]

Statsoft Inc. 2007. STATISTICA (data analysis software system), version 8.0. www.statsoft.com

Yakhontov E.L. \& Formozov N.A. 1992. [Systematic revision of the pika's species complex Ochotona alpinaOchotona hyperborea. 1. Geographic variation in Ochotona alpina] // Vestnik Moskovskogo Universiteta. Biologiya. No.1. P.27-33 [in Russian].

\section{Appendix 1. List of specimens, analyzed in morphometric study. Sample labels, marked} in bold (if $n>4$ ), are followed by localities and museum IDs. For abbreviations see Methods

Yichun-1 - China, Heilongiiang, vicinities of Yichun (IOZCAS 00880, IOZCAS 00902, IOZCAS 03053, IOZCAS 03052, IOZCAS 03050, IOZCAS 00871, IOZCAS 00861, IOZCAS 00893, IOZCAS 00894, IOZCAS 00876, IOZCAS 00866, IOZCAS 00905, IOZCAS 00860, IOZCAS 00878)

Yichun-2 - China, Heilongjiang, vicinities of Yichun (ZIN 38628, MNB 575, MNB 627, MNB 614, MNB 576, MNB 1447, IOZCAS 00891, IOZCAS 00865)

China, Heilongjiang, Yichun, Wuying (IOZCAS 19978)

Wudalianchi - Heilongjiang, Dedu, Wudalianchi (IOZCAS 11359, NWIPB 0006248, NWIPB 0006249, NWIPB 0006250, NWIPB 0006251, NWIPB 0006253, NWIPB 0006254, NWIPB 0006254, NWIPB 0006255, NWIPB 0006256, NWIPB 0006257, NWIPB 0006258, NWIPB 0006259)

Baogetashan - China, Nei Monggol, Dongwuqi, Baogetashan forestry (IOZCAS 27914, IOZCAS 27916, IOZCAS 27913, IOZCAS 27912, IOZCAS 27911, IOZCAS 27915, IOZCAS 24776, IOZCAS 24775)

Genhe - China, Nei Monggol, Ergun Zuoqi, Genhe (MNB 1324, MNB 1138, MNB 1139, MNB 1322, MNB 1114, MNB 1285, MNB 1286, MNB 1126, MNB 1120, MNB 1141, MNB 1145, MNB 1119, IOZCAS 03341, IOZCAS 15647)

Yitulihe - China, Nei Monggol, Ergun Zuoqi, Yitulihe (IOZCAS 11118, IOZCAS 11119, IOZCAS 11117, IOZCAS 03069, IOZCAS 03107, IOZCAS 03166, IOZCAS 03119)

Tulihe - China, Nei Monggol, Yakeshi Shi, Tulihe (IOZCAS 03139, IOZCAS 03123, IOZCAS 03104, IOZCAS 03111, IOZCAS 03117, IOZCAS 03109, IOZCAS 03321) 
Yalu - China, Nei Monggol, Yakeshi Shi, Yalu Railway Station (ZMMU S-82595, ZMMU S-82594, ZMMU S-82598, USNM-270436, USNM-270437, FMNH 49920)

Daling - China, Heilongjiang, Aihui, Daling Linchang (IOZCAS 05345, IOZCAS 05364, IOZCAS 05356, IOZCAS 05305, IOZCAS 05300, IOZCAS 05306, IOZCAS 05298, IOZCAS 05296, IOZCAS 05291, IOZCAS 05308)

China, Nei Monggol, vicinities of Bokhedu (NHM 10.5.1.82: holotype of mantchurica, NHM 10.5.1.83)

China, Nei Monggol, Greater Khinggan Range, without exact locality (ZMMU S-30110, ZMMU S-30109)

China, Heilongjiang, Hama, Bulajiali (IOZCAS 05331, IOZCAS 05333)

China, Nei Monggol, Greater Khinggan Range, upper Chol River (ZMMU S-82597)

China, Nei Monggol, Elunchunqi, Ganhe (IOZCAS 05275)

China, Nei Monggol, Keerqin Zuoyi Qian Qi, Daheigou (IOZCAS 03321)

China, Heilongjiang, Mohe Xian, Xilinji (HNU)

China, Heilongjiang, Mohe Xian, Mohe (IOZCAS 05311)

Bayelga - Russia, Zabaikalskiy Territory, Alexandrozavodskiy District, Bayelga valley (IGU 725, IGU 690, IGU 680, IGU 735, IGU 702, IGU 719)

Alex Zavod - Russia, Zabaikalskiy Territory, Alexandrozavodskiy District, vicinities of Alexandrovskiy Zavod (ZMMU S-82583, ZMMU S-82584, IGU 712, IGU 721, IGU 739)

Kailastuy - Russia, Zabaikalskiy Territory, Krasnokamenskiy District, vicinities of Kailastuy, Bolshoy Chir Mt. (ZIN 25009: holotype of scorodumovi, ZMMU S-82585, ZMMU S-82830, IGU 783, IGU 858, IGU 759)

Russia, Zabaikalskiy Territory, Alexandrozavodskiy District, Kher-Khira River (ZMMU S-178617, ZMMU S178618)

Russia, Zabaikalskiy Territory, Kalganskiy District, Kozlovo (ZMMU S-178615, ZMMU S-178616)

Russia, Zabaikalskiy Territory, Gazimurozavodskiy District, vicinities of Gazimurovskiy Zavod (ZMMU S134658)

Shivki - Russia, Zabaikalskiy Territory, Nerchinskiy District, Shivki, right bank of Shilka River (ZMMU S14806, ZIN 19776, ZMMU S-14805, ZMMU S-17277, ZMMU S-134660)

Russia, Zabaikalskiy Territory, Sretinskiy District, opposite Ust-Chernaya, right bank of Shilka River (ZMMU S-175365)

Russia, Zabaikalskiy Territory, Mogochinskiy District, opposite Zheltuga River, right bank of Shilka River (ZMMU S-175368) 